\title{
The carbonic anhydrase of Clostridium autoethanogenum represents a new subclass of $\beta$-carbonic anhydrases
}

\author{
Bart Pander ${ }^{1} \cdot$ Gemma Harris $^{2}$ • David J. Scott ${ }^{2,3,4} \cdot$ Klaus Winzer $^{1}$ - Michael Köpke ${ }^{5} \cdot$ Sean D. Simpson ${ }^{5}$. \\ Nigel P. Minton ${ }^{1} \cdot$ Anne M. Henstra ${ }^{1}$ (D)
}

Received: 14 May 2019 / Revised: 5 July 2019 / Accepted: 8 July 2019 / Published online: 25 July 2019

(C) The Author(s) 2019

\begin{abstract}
Carbonic anhydrase catalyses the interconversion of carbon dioxide and water to bicarbonate and protons. It was unknown if the industrial-relevant acetogen Clostridium autoethanogenum possesses these enzymes. We identified two putative carbonic anhydrase genes in its genome, one of the $\beta$ class and one of the $\gamma$ class. Carbonic anhydrase activity was found for the purified $\beta$ class enzyme, but not the $\gamma$ class candidate. Functional complementation of an Escherichia coli carbonic anhydrase knock-out mutant showed that the $\beta$ class carbonic anhydrase could complement this activity, but not the $\gamma$ class candidate gene. Phylogenetic analysis showed that the $\beta$ class carbonic anhydrase of Clostridium autoethanogenum represents a novel subclass of $\beta$ class carbonic anhydrases that form the F-clade. The members of this clade have the shortest primary structure of any known carbonic anhydrase.
\end{abstract}

Keywords Carbonic anhydrase $\cdot$ Clostridium autoethanogenum $\cdot$ Gas fermentation · Carbon dioxide $\cdot$ Carbon monoxide Enzyme characterisation

\section{Introduction}

Clostridium autoethanogenum fixes carbon dioxide through the Wood-Ljungdahl pathway (WLP) and produces acetate, ethanol and 2,3-butanediol natively (Abrini et al. 1994; Köpke et al. 2011). As such, use of C. autoethanogenum provides an

Electronic supplementary material The online version of this article (https://doi.org/10.1007/s00253-019-10015-w) contains supplementary material, which is available to authorized users.

Anne M. Henstra

anne.henstra@nottingham.ac.uk

1 Clostridia Research Group, BBSRC/EPSRC Synthetic Biology Research Centre, School of Life Sciences, University of Nottingham, Nottingham NG7 2RD, UK

2 Research Complex at Harwell, Rutherford Appleton Laboratory, Harwell Science and Innovation Campus, Didcot OX11 0FA, UK

3 ISIS Spallation Neutron and Muon Source, Rutherford Appleton Laboratory, Harwell Science and Innovation Campus, Didcot OX11 0QX, UK

4 School of Biosciences, University of Nottingham, Sutton Bonington Campus, Sutton Bonington LE12 5RD, UK

5 LanzaTech Inc., 8045 Lamon Avenue, Suite 400, Skokie, IL, USA attractive way to mitigate the effects of global $\mathrm{CO}_{2}$ release. Besides capture in the WLP, $\mathrm{CO}_{2}$ is also fixed at other metabolic steps, and it was shown, for instance, that elevated $\mathrm{CO}_{2}$ partial pressures benefit the production of 2,3-butanediol (Simpson et al. 2014). In fact, many reactions in microbial metabolism exist where $\mathrm{CO}_{2}$ or bicarbonate are substrates or products (Smith and Ferry 2000). It was proposed that without a mechanism for the rapid interconversion of carbon dioxide and bicarbonate, the turnover rates of common carboxylation reactions that consume bicarbonate would not be feasible in Escherichia coli (Merlin et al. 2003). The interconversion of $\mathrm{CO}_{2}$ and bicarbonate (Eq. (1)) is catalysed by carbonic anhydrase (CA), an enzyme that is essential for most forms of life. To optimise product formation and carbon fixation, knowledge about CA activity is important (Hawkins et al. 2013; Lian et al. 2016).

$\mathrm{H}_{2} \mathrm{O}+\mathrm{CO}_{2} \leftrightarrow \mathrm{HCO}_{3}^{-}+\mathrm{H}^{+}$

There are three major classes of carbonic anhydrase, which are as follows: $\alpha$-CA, $\beta$-CA and $\gamma$-CA. The $\alpha$-class protein is active in monomeric state, while the $\beta$-CAs form dimers, which in turn can stack into tetramers or octamers. The $\gamma$ CAs form homotrimeric structures (Lindskog 1997; Ferry 
2010; Rowlett 2010). In addition, $\delta$-CA, $\zeta$-CA and $\eta$-CA classes were proposed for non-canonical CA enzymes present in diatoms and Plasmodium sp. (Del Prete et al. 2014). An initially identified $\varepsilon$-CA class of carboxydosome-specific CAs was later reclassified as a subgroup of $\beta$-CA after it was recognised that these enzymes were structurally similar, despite little sequence similarity (Sawaya et al. 2006). This specific subclass will be referred to as the E-clade of $\beta$-CA in the remainder of this article.

Carbonic anhydrases (EC 4.2.1.1) are metalloenzymes. All known CAs function with a $\mathrm{Zn}^{2+}$ metal ion cofactor in their active site, but some are functional with other metal ions as well. In $\gamma$-CAs of anaerobic microorganisms, $\mathrm{Fe}^{2+}$ or $\mathrm{Co}^{2+}$ can functionally replace $\mathrm{Zn}^{2+}$, while the $\zeta$-class $\mathrm{CA}$ is also functional with $\mathrm{Cd}^{2+}$ (Kumar and Ferry 2014; Supuran 2016). The metal ions are coordinated in the active site by three histidines (for $\alpha-, \gamma-, \delta$ - and $\eta$-class CAs) or one histidine and two cysteines (for $\beta$ - and $\zeta$-class CAs). These amino acids are arranged in a distinct motif for each CA class (Hewett-Emmett and Tashian 1996; Ferry 2010; Rowlett 2010; Capasso and Supuran 2015). The diverse class of microbial $\beta$-CA is divided in five clades, A-D (Smith and Ferry 2000) plus the former $\varepsilon$-CA class that we will recognise here as the E clade. All $\beta$-CA sport the common metalcoordinating active-site motif CxDxR-G-HxxC (Lindskog 1997; Ferry 2010; Rowlett 2010).

The physiological role of CA enzymes is diverse, but not always clear. In animals, they are essential for rapid gas exchange and other functions, such as $\mathrm{pH}$ homeostasis. Since specific CAs act in specific tissues with specific inhibition patterns, CAs are common drug targets (Supuran and Scozzafava 2007). In plants and algae, CAs have a function in carbon dioxide diffusion facilitation and carbon concentration mechanisms (Moroney et al. 2001; Moroney et al. 2011). In prokaryotes, CAs are almost ubiquitous. Proposed functions of CAs in prokaryotes are to act in carbon concentration (Cannon et al. 2010), carbon dioxide transport (Gai et al. 2014), facilitation of carbon dioxide or bicarbonateconsuming or -producing reactions (Smith and Ferry 2000; Merlin et al. 2003; Supuran and Ferry 2013), pH homeostasis (Sachs et al. 2005) and acetate transport facilitation (BrausStromeyer et al. 1997). Most bacteria can grow under low carbon dioxide partial pressures. For this, a CA gene seems to be essential since species that need high carbon dioxide partial pressures (capnophiles) often have no detectable CA activity and some have lost CA genes (Ueda et al. 2008; Ueda et al. 2012). For the capnophile Campylobacter jejuni, it was shown that it contains a CA that is only active at high $\mathrm{pH}$, but not under normal physiological pH (Al-Haideri et al. 2016). Also, CA deletion mutants often can only grow under high carbon dioxide partial pressures (Kusian et al. 2002; Merlin et al. 2003; Kumar et al. 2013), making them functional capnophiles. In E. coli, a specific CA, CynT, is part of cyanate metabolism operon that is tightly controlled and induced by cyanate or azide (Guilloton et al. 1993). When the constitutively expressed CA can gene of $E$. coli was disrupted, the mutant strain (E. coli EDCM636) was unable to grow under atmospheric carbon dioxide pressure. Addition of azide restored its normal growth (Merlin et al. 2003). This strain is useful for studies to test if putative CA genes can complement CA activity.

Production of 3-hydroxypropionate by the expression of bicarbonate-dependent reactions in Pyrococcus furiosus that lacks a functional CA benefited greatly from the expression of functional CA genes (Lian et al. 2016) underpinning the importance of CAs in a biotechnological context.

Previously, a diverse set of acetogens, i.e., bacteria using the WLP, screened for CA activity showed a range of CA activities (Braus-Stromeyer et al. 1997). One model of acetogen, Acetobacterium woodii, had high CA activity, but the other model of acetogen, Moorella thermoacetica, showed little to no activity. No close relatives of $C$. autoethanogenum were included in this CA screening.

Here, we identified two putative CA genes in the genome of $C$. autoethanogenum. One of these encoded a dimeric enzyme that was indeed active as CA. The gene formed a new F clade in the $\beta$-class of CA. This new clade represents CAs with the shortest primary structure known.

\section{Materials and methods}

\section{Bioinformatics}

To search the online protein databases, we used NCBI blastp, PSI-Blast, Delta-Blast, PHI-Blast and tblastn algorithms (Sayers et al. 2012). For alignments, we used the MUSCLE algorithm (Edgar 2004) in both Ugene (Okonechnikov et al. 2012) and Mega7.0 (Kumar et al. 2016). Consensus logos were made using JalView (Waterhouse et al. 2009). Phylogenetic analysis was performed in mrBayes (Ronquist et al. 2012) and Mega7.0, and figures were made in Figtree (Rambaut 2014). To find the optimal evolutionary model, we used Prottest (Darriba et al. 2011) and Mega7.0. Structural protein modelling was done by Phyre2 (Kelley et al. 2015). Protparam of the ExPASy server (Gasteiger et al. 2005) was used to calculate predicted parameters of proteins.

\section{Strains and growth conditions}

C. autoethanogenum JA1-1 (DSM 10061) was obtained from the Deutsche Sammlung von Mikroorganismen und Zellkulturen GmbH (Germany). E. coli EDCM636 was from the Coli Genetic Stock Centre (CGSC, New Haven, CT, USA). C. autoethanogenum was grown in YTF medium (yeast extract $10 \mathrm{~g} \mathrm{l}^{-1}$, tryptone $16 \mathrm{~g}^{-1}$, fructose $10 \mathrm{~g} \mathrm{l}^{-1}$, 
$\left.\mathrm{NaCl} 0.2 \mathrm{~g} \mathrm{l}^{-1}\right)$ with trace elements $\left(\mathrm{H}_{3} \mathrm{BO}_{3} 100 \mu \mathrm{g} \mathrm{l}^{-1}\right.$, $\mathrm{MnCl}_{2} \cdot 4 \mathrm{H}_{2} \mathrm{O} 230 \mu \mathrm{g} \mathrm{l} \mathrm{l}^{-1}, \mathrm{FeCl}_{2} \cdot 4 \mathrm{H}_{2} \mathrm{O} 780 \mu \mathrm{g} \mathrm{l^{-1 }}$, $\mathrm{CoCl}_{2} \cdot 6 \mathrm{H}_{2} \mathrm{O} 103 \mu \mathrm{g} \mathrm{l}^{-1}, \mathrm{NiCl}_{2} \cdot 6 \mathrm{H}_{2} \mathrm{O} 602 \mu \mathrm{g} \mathrm{l}^{-1}, \mathrm{ZnCl}_{2}$ $78 \mu \mathrm{g} \mathrm{l}^{-1}, \mathrm{CuSO}_{4} \cdot 5 \mathrm{H}_{2} \mathrm{O} 50 \mu \mathrm{g} \mathrm{l}^{-1}, \mathrm{AlK}\left(\mathrm{SO}_{4}\right)_{2} \cdot 12 \mathrm{H}_{2} \mathrm{O}$ $50 \mu \mathrm{g} \mathrm{l}^{-1}, \mathrm{Na}_{2} \mathrm{SeO}_{3} 58 \mu \mathrm{g} \mathrm{l}{ }^{-1}, \mathrm{Na}_{2} \mathrm{WO}_{4} 53 \mu \mathrm{g} \mathrm{l} \mathrm{l}^{-1}$, $\mathrm{Na}_{2} \mathrm{MbO}_{4} \cdot 2 \mathrm{H}_{2} \mathrm{O} 52 \mu \mathrm{g} \mathrm{l}^{-1}$ ) and vitamins (p-aminobenzoate $57 \mu \mathrm{g} \mathrm{l}^{-1}$, riboflavin $52 \mu \mathrm{g} \mathrm{l}^{-1}$, thiamine $100 \mu \mathrm{g} \mathrm{l}^{-1}$, nicotinate $103 \mu \mathrm{g} \mathrm{l^{-1 }}$, pyridoxine $255 \mu \mathrm{g} \mathrm{l}^{-1}$, calcium pantothenate $52 \mu \mathrm{g} \mathrm{l}^{-1}$, cyanocobalamin $39 \mu \mathrm{g} \mathrm{l}^{-1}$, biotin $11 \mu \mathrm{g} \mathrm{l}^{-1}$, folate $24 \mu \mathrm{g} \mathrm{l}^{-1}$, thioctic acid $25 \mu \mathrm{g} \mathrm{l^{-1 }}$, at $\mathrm{pH}$ 5.8. All cultures of C. autoethanogenum were grown at $37^{\circ} \mathrm{C}$ in a MG1000 anaerobic workstation with TG airlock (Don Whitley, UK).

All E. coli strains were grown on LB medium (tryptone $10 \mathrm{~g} \mathrm{l}^{-1}$, yeast extract $5 \mathrm{~g} \mathrm{l}^{-1}, \mathrm{NaCl} 10 \mathrm{~g} \mathrm{l}^{-1}$ ). To induce the Cyn operon and thus enable growth of E. coli EDCM636, $0.1 \mathrm{mM}$ sodium azide $(\mathrm{Az})$ was added to the medium. Erythromycin (Em) was used at a concentration of $500 \mu \mathrm{g} \mathrm{ml}^{-1}$ and ampicillin at $100 \mu \mathrm{g} \mathrm{ml}^{-1}$ when present.

\section{Plasmid construction}

Enzymes used for subcloning and PCR were purchased from New England Biolabs (NEB, MA, USA). All other chemicals were purchased from Sigma-Aldrich except for Bugbuster (Merck Millipore, Germany) and Strep-Tactin sepharose (IBA, Germany).

Plasmids for heterologous overexpression of CA genes were constructed as follows: Genes were amplified by polymerase chain reaction (PCR) using genomic DNA of C. autoethanogenum as template. The genomic DNA was isolated using the Genelute (Sigma) genomic DNA isolation kit. PCR was performed with primers (Table 1) FbCA and $\mathrm{RbCA}$ to obtain an untagged version of caut- $b C A$ and primers FbCA and RbCAstrep to obtain a C-terminal strep-tagged version of the same gene. Similarly, primers FgCA and $\mathrm{RgCA}$ were used to obtain an untagged caut-gCA and the primers $\mathrm{FgCA}$ and $\mathrm{RgCAStrep}$ to obtain a C-terminal streptagged version of the $g C A$ gene. These PCR fragments were subcloned into pMTL82252 (Heap et al. 2009) using NdeI, EcoRI and T4-ligase. To construct His-tagged versions of Caut-bCA and Caut-gCA, we performed PCR with primers BCAECPF and BCAECPR or FPCA1 and RPCA1, respectively. The resulting fragments were cloned into a pET16b (Novagen) plasmid using NdeI and BamHI and T4-ligase. E. coli $\mathrm{DH} 5 \alpha$ chemically competent cells (NEB) were transformed with these plasmids. Plasmids were isolated using Monarch plasmid isolation kit (NEB) and Sanger sequenced by Eurofins using the FpMTL $8 \times x 5 x$ primer for the pMTL 82252 plasmids and the pET16b F primer for the pET16b plasmids.

E. coli BL21(DE3) pLysS was transformed with pET16bbCA and pET16b-gCA. E. coli EDCM636 was transformed with pMTL82252-bCA, pMTL82252-bCAstrepC and
pMTL82252-gCA. The transformed cells were plated on LB agar with Em and on LB agar with Em and Az. Colonies were restreaked on LB agar, LB agar with Em, LB agar with Em and $\mathrm{Az}$ and LB agar with Az, to study the ability of the caut$b C A$ and caut-gCA genes to complement the $\triangle \mathrm{CA}$ mutation of $E$. coli EDCM636s.

\section{Protein purification}

To produce and purify the His-tagged putative CA enzymes from the BL21(DE3) cells, $5 \mathrm{ml} \mathrm{LB}$ was inoculated from a $80{ }^{\circ} \mathrm{C}$ stock and grown overnight at $225 \mathrm{rpm}, 37^{\circ} \mathrm{C}$. This $\mathrm{O} / \mathrm{N}$ culture was used to inoculate $5 \times 100 \mathrm{ml} \mathrm{LB}$ in $500 \mathrm{ml}$ Erlenmeyer flasks to a start $\mathrm{OD}_{600}$ of approximately 0.05 and incubated in a shaking incubator at $225 \mathrm{rpm}, 37^{\circ} \mathrm{C}$. At $\mathrm{OD}_{600}$, $0.3-0.7$ cells were induced with IPTG (Isopropyl $\beta$-D-1thiogalactopyranol), a $0.5 \mathrm{mM}$ final concentration, and incubated at $30^{\circ} \mathrm{C}$ for $3-5 \mathrm{~h}$. Cells were harvested by centrifugation, and cells were lysed with a QS1 probesonicator (Nanolabs, MA, USA) or with BugBuster® Plus Lysonase ${ }^{\mathrm{TM}}$. An additional centrifuge step was used to create cell-free extract. The protein was purified using a $5 \mathrm{ml}$ HisTrap® HP collumn (GE Healthcare Life Sciences, Buckinghamshire, UK) and $300 \mathrm{mM}$ imidazole for elution buffer. For the production of the STREP-tagged enzyme, $300 \mathrm{ml}$ of overnight culture (LB, shaking, $37^{\circ} \mathrm{C}$ ) E. coli EDCM636 pMTL82252-bCAstrepC or EDCM636 pMTL82252-gCAstrepC was harvested by centrifugation and lysed using BugBuster Plus Lysonase with Avidin added at one small crystal per $30 \mathrm{ml}$. The Caut-bCA protein was purified using Strep-Tactin Sepharose using $100 \mathrm{mM}$ Tris pH 8 with $150 \mathrm{mM} \mathrm{NaCl}$ as wash buffer. For elution, $0.5 \mathrm{mg} \mathrm{ml}^{-1}$ desthiobiotin was added to the wash buffer. Samples of all purification fractions were resolved on a NuPAGE Novex 4-12\% Bis-Tris Protein Gels (ThermoFisher, Waltham, MA, USA) to assess purity and yield. Protein concentration was further analysed using a NanoDrop Lite photospectrometer (Thermo-Scientific, Wilmington, DE, USA).

\section{Analytical ultracentrifugation}

For characterisation of the purified Caut-bCA by analytical ultracentrifugation, sedimentation velocity scans were recorded for a 2 -fold protein dilution series, starting at $0.7 \mathrm{mg} \mathrm{ml}^{-1}$. The analysis was performed at 50,000 rpm, using a Beckman XL-I analytical ultracentrifuge with an An-50Ti rotor, and results were obtained by absorbance measured at $280 \mathrm{~nm}$ and interference optical detection systems. The density and viscosity of the buffer were measured using a DMA $5000 \mathrm{M}$ densitometer equipped with a Lovis $200 \mathrm{ME}$ viscometer module. The partial specific volume for the protein was calculated using Sednterp from the amino acid sequence. Data were 
Table 1 Primers used in this study

\begin{tabular}{|c|c|}
\hline Primer name & Primer sequence \\
\hline FgCAOE & TATACATATGATAAGAAAATTTGAACATTAC \\
\hline $\mathrm{RgCAOE}$ & TATAGAATTCTAATATTCACTATAATTTTTAGC \\
\hline FgCAOEStrepN & $\begin{array}{l}\text { TATACATATGTGGTCACATCCTCAATTTGAAA } \\
\text { AAATGA } \\
\text { TAAGAAAATTTGAACATTAC }\end{array}$ \\
\hline RgCAOEStrepC & $\begin{array}{l}\text { TATAGAATTCTTATTTTTCAAATTGAGGATGTGACCAA } \\
\text { TATTCACTATAATTTTTAGC }\end{array}$ \\
\hline $\mathrm{RgCAOEHisC}$ & $\begin{array}{l}\text { TATAGAATTCATGATGATGATGATGATGATGATGATTA } \\
\text { TATTCACTATAATTTTTAGC }\end{array}$ \\
\hline $\mathrm{FbCAOE}$ & $\begin{array}{l}\text { TATACATATGTTGAACAGTGATTTTGCTGTAT } \\
\text { TGTTAAATTGTATG }\end{array}$ \\
\hline $\mathrm{RbCAOE}$ & $\begin{array}{l}\text { TATAGAATTCTAAAGTTTTTCCACTTCGAAAT } \\
\text { TCTCATTTATC }\end{array}$ \\
\hline FbCAOEStrepN & $\begin{array}{l}\text { TATACATATGTGGTCACATCCTCAATTTGAAAAATTGA } \\
\text { ACAGTGATTTTGCTGTATTGTTAAATTGTATG }\end{array}$ \\
\hline RbCAOEStrepC & $\begin{array}{l}\text { TATAGAATTCTTATTTTTCAAATTGAGGATGT } \\
\text { GACCAAAGTTTTTCCACTTCGAAATTCTCATTTATC }\end{array}$ \\
\hline FpMTL8xx5x & GAAGTACATCACCGACGAGC \\
\hline $\mathrm{FPgCA}$ & $\begin{array}{l}\text { GTTGTCCATATGATAAGAAAATTTGAACAACA } \\
\text { TTACATACCAG }\end{array}$ \\
\hline $\mathrm{RPgCA}$ & GTTGTTGGATCCCTAATATTCACTATAATTTTTAGCCC \\
\hline BCAECPF & GTTGTCCATATGTTGAACAGTGATTTTGCTGTATTG \\
\hline BCAECPR & GTTGTTGGATCCCTAAAGTTTTTCCACTTCG \\
\hline FPCA1 & $\begin{array}{l}\text { GTTGTCCATATGATAAGAAAATTTGAACAACA } \\
\text { TTACATACCAG }\end{array}$ \\
\hline RPCA1 & GTTGTTGGATCCCTAATATTCACTATAATTTTTAGCCC \\
\hline pET16b_F & GATCCCGCGAAATTAATACGA \\
\hline
\end{tabular}

processed using SEDFIT, fitting to the $\mathrm{c}(\mathrm{s})$ or noninteracting discrete species (NIDS) model (Schuck 2000).

\section{CA activity assay}

To determine CA activity, we developed an assay using a Tecan M1000-Pro (Männedorf, Switzerland) plate reader with auto injector, based on previous methods (Wilbur and Anderson 1948; Sundaram et al. 1986; Fasseas et al. 2011; Gai et al. 2014). We have validated the assay using bovine CA (Sigma) and C. jejuni CanB (Al-Haideri et al. 2016) (kindly supplied by D.J. Kelly of the University of Sheffield). The assay buffer was $50 \mathrm{mM}$ HEPES, $50 \mathrm{mM} \mathrm{Na}_{2} \mathrm{SO}_{4}, 50 \mathrm{mM}$ $\mathrm{MgSO}_{4}, 0.004 \%(w / v)$ phenol red at several $\mathrm{pH}$ values. The substrate for the hydration reaction was carbon dioxidesaturated water, produced by bubbling carbon dioxide through demineralised water at $20^{\circ} \mathrm{C}$ for $30 \mathrm{~min}$. This should result in $34 \mathrm{mM} \mathrm{CO}_{2}$ (Diamond and Akinfiev 2003); for lower concentrations, the $\mathrm{CO}_{2}$-saturated water was diluted with demineralised water that was sparged with $\mathrm{N}_{2}$ for 30 min. The substrate of the dehydration reaction was $\mathrm{KHCO}_{3}$ at $100 \mathrm{mM}$. For the hydration reaction, $120 \mu \mathrm{l}$ of assay buffer was mixed with $10 \mu$ enzyme sample or $10 \mu l$ sample buffer in a 96-well plate. After measuring the baseline for $4 \mathrm{~s}, 120 \mu \mathrm{l}$ of substrate was injected. For the dehydration reaction, $140 \mu \mathrm{l}$ and $10 \mu \mathrm{l}$ enzyme samples or $10 \mu \mathrm{l}$ sample buffer was used, after $4 \mathrm{~s}$ baseline measurement $50 \mu \mathrm{l}$ substrate was added. Change of absorption was measured at $557 \mathrm{~nm}$ for $40 \mathrm{~s}$ at a temporal resolution of $200 \mathrm{~ms}$. The average change in absorption $\mathrm{s}^{-1}$ of the first ten readings was taken as the initial speed of the reaction. The $\mathrm{Km}$ and $V \max$ were calculated using the Michaelis and Menten (1913) curve fitting tool of GraphPad Prism 7.00 (La Jolla, CA, USA).

\section{Results}

To establish if $C$. autoethanogenum harbours CA genes in its genome, we collected $41 \mathrm{CA}$ protein sequences covering the $\alpha-, \beta-, \gamma-$ and $\delta$-CA classes of organisms from all domains of life. We assembled consensus sequences of the $\alpha-, \beta$ - and $\gamma$ $\mathrm{CA}$ classes and then used amino acid sequences and the assembled consensus sequences to search the genome of C. autoethanogenum. One gene that encoded a putative $\gamma$ CA (Caut-gCA, CLAU_2699) was found with a PSIBLAST E-value of $3 \mathrm{e}-50$ and $54 \%$ sequence identity to the 
Fig. 1 Complementation of E. coli $\mathrm{EDCM} 636$ with Caut-bCA and Caut-gCA. Strains of E. coli EDCM636 transformed with caut-bCA or caut-gCA on plasmid, and control strains were streaked on LB agar medium (a), LB with erythromycin and azide (b), LB with erythromycin (c) and LB with azide (d). E. coli strains indicated by roman numerals were as follows: (I) EDCM636 ( $\Delta$ Can), (II) EDCM636 ( $\Delta$ Can)pMTL82252, (III) EDCM636 ( $\triangle$ Can)-pMTL82252-bCA, (IV) EDCM636 ( $\triangle$ Can)pMTL82252-gCA and (V) DH5 $\alpha$

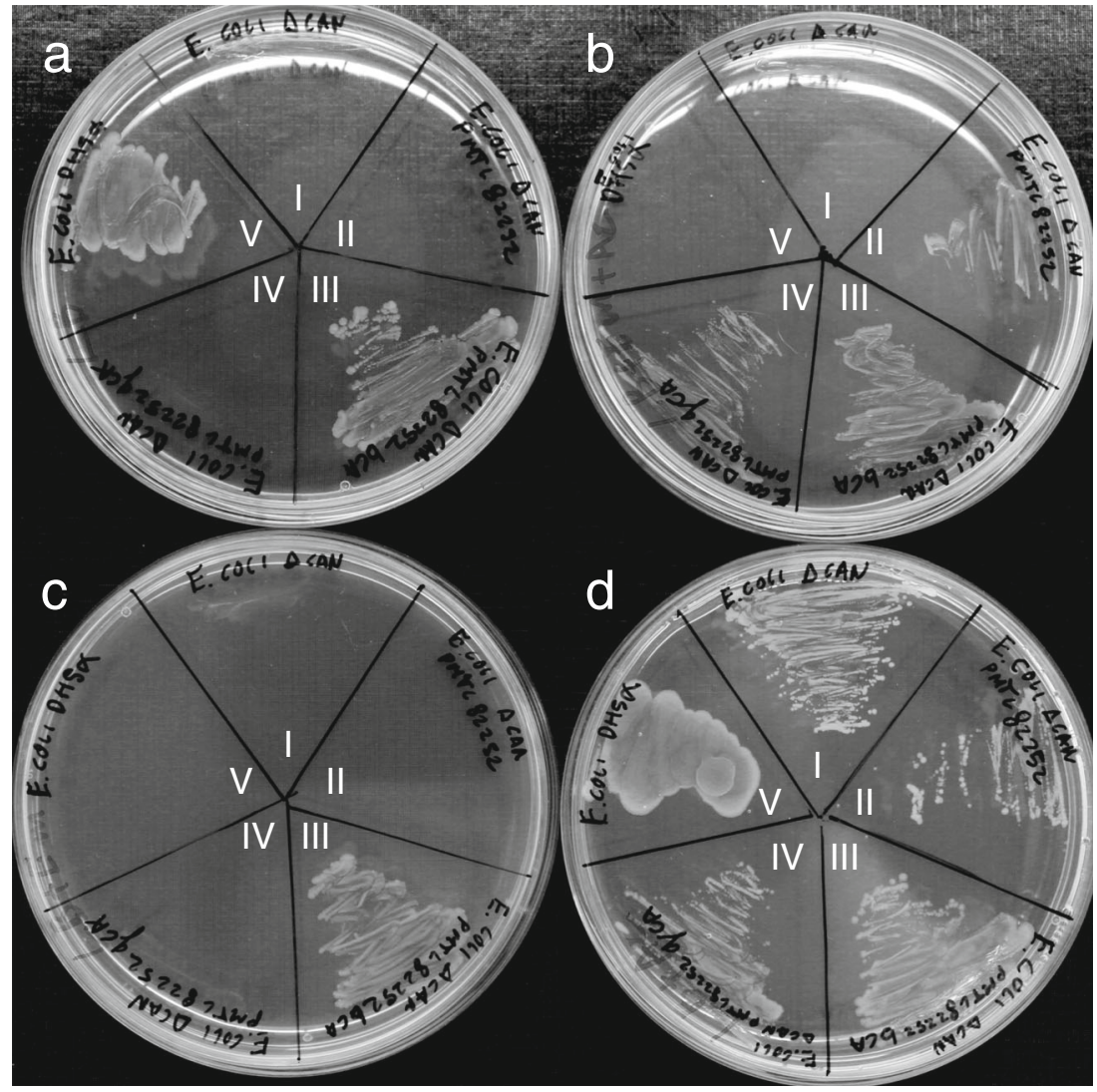

$\gamma$-CA consensus sequence. This gene was annotated as a hexapeptide repeat-containing protein, a feature that exists in $\gamma$-CA (Iverson et al. 2000). It had the three important metalbinding histidine residues conserved but lacks glutamine and asparagine residues that were found to be important in the canonical $\gamma$-CA (Cam) from Methanosarcina thermophile (Ferry 2010). A gene coding for a putative $\beta$-CA (CautbCA, locus tag CLAU_3021) was found using the $\beta$-CA

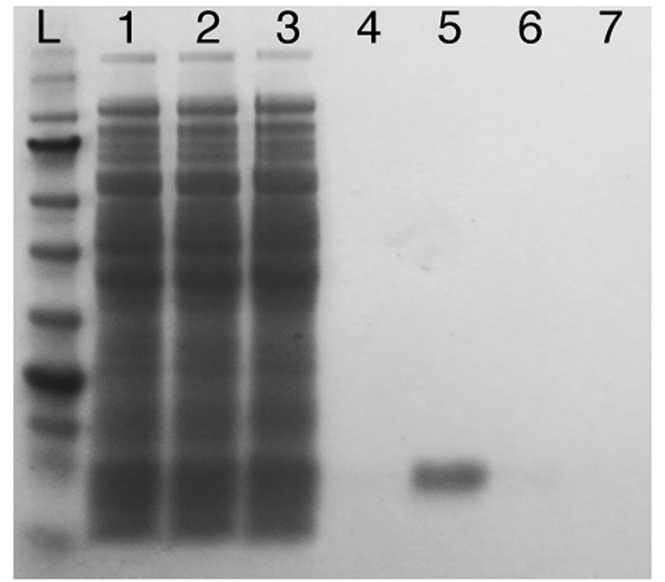

Fig. 2 SDS-PAGE analysis of Caut-bCAstrepC protein purification fractions. Lane L, NEB protein ladder P7712; lane 1, lysate; lane 2, column flow through; lane 3, initial wash; lane 4, final wash; lane 5, first eluate; lane 6 , second eluate; lane 7 , third eluate consensus sequence in PSI-BLAST and matched with an $E$ value of $1 \mathrm{e}-80$. Despite the low similarity to other $\beta$-CAs, this gene encodes a protein that contains the motifs CxDxR and HxxC, which are known to be important for the activity of $\beta$ CAs (Smith and Ferry 2000; Smith et al. 2002).

In recently published transcriptomics data, caut-bCA is consistently higher expressed than caut-gCA (148.177 FPKM vs 71.7564 FPKM) (Marcellin et al. 2016). Downstream of the caut-gCA gene, a peptidase M14 carboxypeptidase was present, which has no obvious link to CAs except that both are $\mathrm{Zn}$ metalloenzymes. The caut-bCA gene was part of a cluster (CLAU_3019-CLAU_3023) of five genes with similar expression pattern (unpublished RNAseq data). A yop $X$ gene and a single-stranded DNA-binding protein-encoding gene that are present in this cluster indicate a phage origin. The gene immediately downstream of Caut$b C A$ was annotated as a deoxyuridine 5 'triphosphate nucleotidohydrolase which indicates a potential function in pyrimidine metabolism where $\mathrm{HCO}_{3}{ }^{-}$is an important factor.

Protparam results showed that the 124 amino acid residues of Caut-bCA formed a stable protein with a molecular weight of $14.2 \mathrm{kDa}$ and $\mathrm{pI}$ of 5.3. The 168 amino acid residues of Caut-gCA were expected to form an unstable protein with a mass of $18.3 \mathrm{kDa}$ and $\mathrm{pI}$ of 6.4. Phyre2 structural modelling showed Caut-bCA as a small but not untypical $\beta$-CA with an accessible active site. 

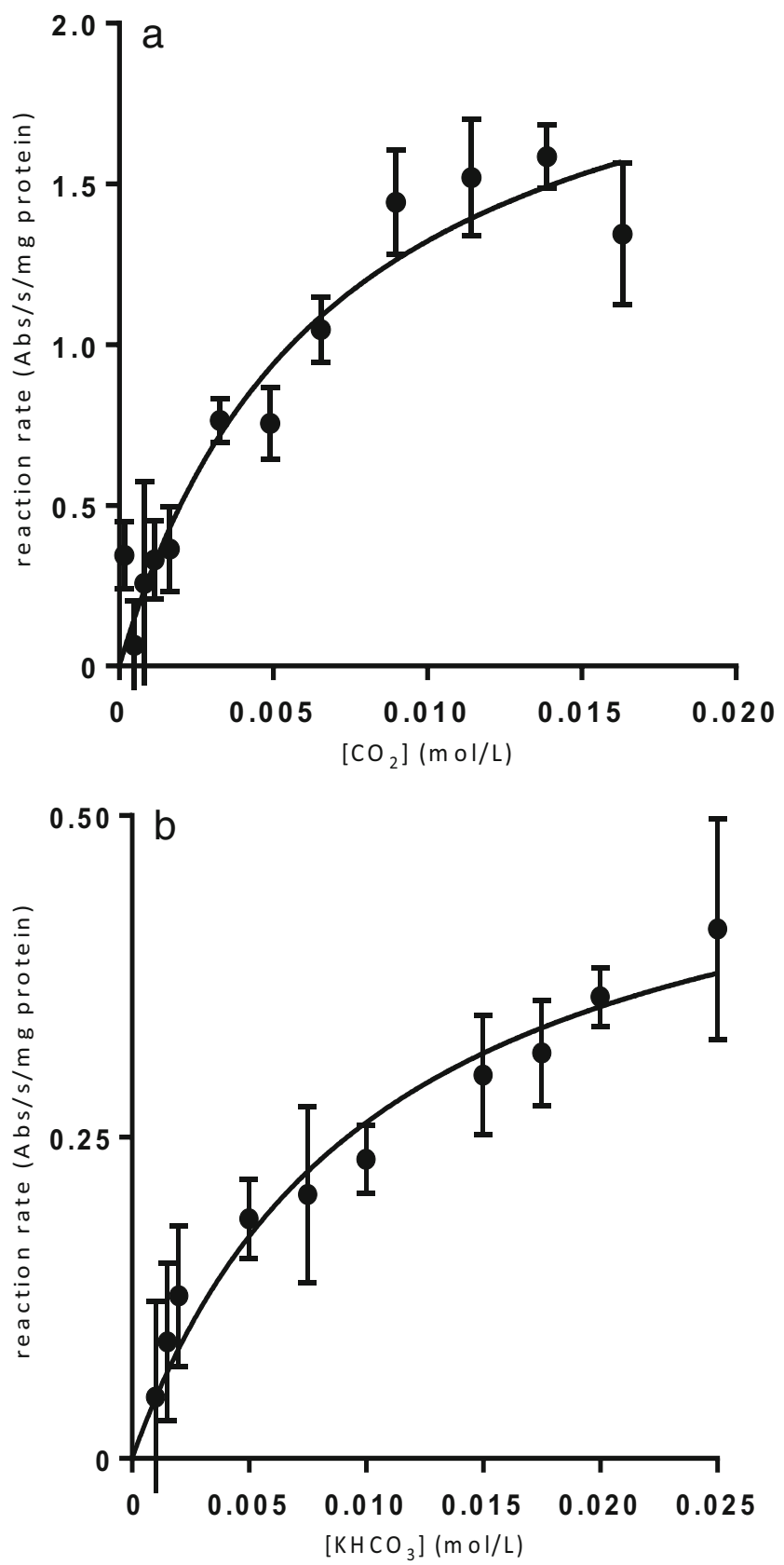

Fig. 3 The reaction rates of $\mathrm{CO}_{2}$ hydration (left) and $\mathrm{KHCO}_{3}$ dehydration (right) are shown. The values are the difference between the uncatalysed and catalysed rates measured by absorption at $557 \mathrm{~nm}$. The enzyme was assayed in a buffer of $50 \mathrm{mM}$ HEPES, $50 \mathrm{mM} \mathrm{MgSO}_{4}, 50 \mathrm{~mm} \mathrm{Na}_{2} \mathrm{SO}_{4}$, $0.004 \%(w / v)$ phenol red $\mathrm{pH} 8.3$ with $\mathrm{CO}_{2}$ as a substrate, and $\mathrm{pH} 6$ for $\mathrm{KHCO}_{3}{ }^{-}$substrate at $20^{\circ} \mathrm{C}$. The data points represent the mean and SD, $N \geq 4$. The curve is the fit to the Michaelis-Menten equation

\section{Functional complementation of E. coli Can<FLK2>}

The Can disruption mutant of E. coli EDCM636 (Merlin et al. 2003), which lacks a constitutively expressed CA and is therefore unable to grow under atmospheric carbon dioxide pressure, was used to test if Caut-bCA and Caut-gCA exhibited CA activity. When transformed with plasmids carrying the
caut-bCA or caut-gCA gene, only E. coli EDCM636 complemented with caut- $b C A$ was able to grow in the absence of azide (Fig. 1). E. coli EDCM636 cells transformed with pMTL82252-bCAstrepC also grew without the absence of azide, indicating the $\mathrm{C}$-terminal strep tag did not impair activity of the enzyme. We did find that E. coli EDCM636 cells infrequently reverted to the native phenotype and grow in the absence of azide. Therefore, we repeated this experiment three times with fresh batches of competent cells that did not show WT phenotypes.

\section{Development of a high-throughput CA activity assay method}

To establish whether the identified genes encode for active CA enzymes, we developed a high-throughput activity assay that was performed in 96-well format. As far as the authors know, this is the first description of performing CA assays in 96-well format. The performance of the assay was assessed with bovine $\alpha$-CA with a dose-effect response in the range of $0.003-3 \mu \mathrm{g} \mathrm{ml}^{-1}$ of enzyme. It was further validated by measuring the $K_{\mathrm{M}}$ of bovine $\alpha$ $\mathrm{CA}$ and the $\mathrm{pH}$-specific activity of the $C$. jejuni $\mathrm{CanB}$, a $\beta$ CA (Al-Haideri et al. 2016). The method replicated the specific $\mathrm{pH}$ profile of $C$. jejuni $\mathrm{CanB}$, typical of type II $\beta$-CAs, and the $K_{\mathrm{M}}$ was determined as $4.7 \pm 2 \mathrm{mM}$ at $20{ }^{\circ} \mathrm{C}$. Al-Haideri et al. found a $K_{\mathrm{M}}$ of $34 \pm 10 \mathrm{mM}$ at $4{ }^{\circ} \mathrm{C}$; however, this temperature could not be replicated in our Tecan M1000-Pro. The $K_{\mathrm{M}}$ of bovine CA was determined as $17 \pm 4 \mathrm{mM}$ while published values vary between 12 and $1.1 \mathrm{mM}$ (Kernohan 1964; Iqbal et al. 2014). We continued to apply this assay in the characterisation of C. autoethanogenum CAs.

\section{Enzyme characterisation}

To characterise the specific activity of the putative CAs of C. autoethanogenum, they were heterologously expressed, purified and assayed for the activity. Purification of the Caut-bCA and Caut-gCA with N-terminal His-tag (Hochuli et al. 1988) on a pET16b plasmid expressed in BL21(DE3) pLysS cells did not reliably yield active enzymes (data not shown). A C-terminal STREPII-tagged (Schmidt and Skerra 2007) Caut-bCA protein, expressed from pMTL 82252 in the E. coli EDCM636 strain, was reliable purified (Fig. 2) and used for further characterisation of the enzyme. We did not manage to show CA activity for Caut-gCA or CautgCAstrepC with any of the tested systems and did not further characterise this enzyme. The developed high-throughput CA assay method was used to measure the kinetic parameters of the hydration reaction of the Caut-bCAstrepC enzyme (Fig. 3). The $K_{\mathrm{M}}$ for the hydration reaction was measured at $6.8 \pm 1.6 \mathrm{mM}$, and, for the dehydration reaction, it was $10.5 \pm$ 
Table 2 Kinetic parameters of Caut-bCA and previously described beta-carbonic anhydrases

\begin{tabular}{|c|c|c|c|c|c|c|c|c|}
\hline \multirow[t]{2}{*}{ Species } & \multirow{2}{*}{$\begin{array}{l}\text { Monomer } \\
\text { size }(\mathrm{kDa})\end{array}$} & \multirow{2}{*}{$\begin{array}{l}\text { Oligomeric } \\
\text { state }\end{array}$} & \multirow[t]{2}{*}{ Clade } & \multicolumn{2}{|l|}{ Hydration } & \multicolumn{2}{|c|}{ Dehydration } & \multirow[t]{2}{*}{ Reference } \\
\hline & & & & $K_{\text {cat }}\left(\mathrm{s}^{-1}\right)$ & $\begin{array}{l}K_{\mathrm{cat}} / K_{\mathrm{M}} \\
\left(\mathrm{s}^{-1} \mathrm{M}^{-1}\right)\end{array}$ & $K_{\text {cat }}\left(\mathrm{s}^{-1}\right)$ & $\begin{array}{l}K_{\mathrm{cat}} / K_{\mathrm{M}} \\
\left(\mathrm{s}^{-1} \mathrm{M}^{-1}\right)\end{array}$ & \\
\hline $\begin{array}{l}\text { Clostridium } \\
\text { autoethanogenum }\end{array}$ & 14.2 & Dimer & $\mathrm{F}$ & $2.1 \times 10^{5}$ & $3.1 \times 10^{7}$ & $6.3 \times 10^{4}$ & $6.0 \times 10^{6}$ & This study \\
\hline Pisum sativum & 24.2 & Octamer & B & $4 \times 10^{5}$ & $1.8 \times 10^{7}$ & NA & NA & $\begin{array}{l}\text { Kisiel and Graf (1972); Johanson } \\
\text { and Forsman (1993) }\end{array}$ \\
\hline $\begin{array}{l}\text { Cryptococcus } \\
\text { neoformans }\end{array}$ & 26 & Dimer & A & $3.9 \times 10^{5}$ & $4.3 \times 10^{7}$ & NA & NA & Innocenti et al. (2008) \\
\hline Drosophila melanogaster & 30.0 & Dimer & $\mathrm{B}$ & $9.5 \times 10^{5}$ & $1.1 \times 10^{8}$ & NA & NA & Syrjänen et al. (2010) \\
\hline $\begin{array}{l}\text { Clostridium perfringens } \\
\text { strain } 13\end{array}$ & 21.3 & Tetramer & $\mathrm{D}$ & $1.5 \times 10^{4}$ & $4.8 \times 10^{6}$ & NA & NA & Kumar et al. (2013) \\
\hline $\begin{array}{l}\text { Methanobacterium } \\
\text { thermautotrophicus }\end{array}$ & 18.9 & Tetramer & $\mathrm{D}$ & $1.7 \times 10^{4}$ & $5.9 \times 10^{6}$ & NA & NA & Smith and Ferry (1999) \\
\hline $\begin{array}{l}\text { Halothiobacillus } \\
\text { neapolitanus }\end{array}$ & 57.3 & Dimer & $\mathrm{E}$ & $8.9 \times 10^{5}$ & $2.8 \times 10^{7}$ & $4.6 \times 10^{4}$ & $4.9 \times 10^{6}$ & $\begin{array}{l}\text { Sawaya et al. (2006); Heinhorst } \\
\text { et al. (2006) }\end{array}$ \\
\hline $\begin{array}{l}\text { Salmonella enterica } \\
\quad(s t C A I)\end{array}$ & 24.8 & NA & A & $7.9 \times 10^{5}$ & $8.3 \times 10^{7}$ & NA & NA & Nishimori et al. (2011) \\
\hline $\begin{array}{l}\text { Salmonella enterica } \\
\quad(\text { stCAII })\end{array}$ & 26.6 & NA & $\mathrm{C}$ & $8.9 \times 10^{5}$ & $5.2 \times 10^{7}$ & NA & NA & Nishimori et al. (2011) \\
\hline
\end{tabular}

NA, not available

$2.5 \mathrm{mM}$. The measured kinetic parameters of the hydration reaction were comparable with those of the other reported $\beta$ CAs (Table 2), and comparative data is mostly lacking for the dehydration reaction. Incubation of the purified enzyme at $95^{\circ} \mathrm{C}$ for $10 \mathrm{~min}$ caused total loss of activity (data not shown).

Analytical ultracentrifugation of Caut-bCAstrepC (Table 3 and Fig. 4) showed that molecular weight of $30 \mathrm{kDa}$ obtained for the main peak of the derived sedimentation coefficient distribution was consistent with that of a dimer.

\section{Phylogeny}

The low identity of the putative Caut-bCA with known $\beta$ CAs triggered further phylogenetic analysis. A Bayesian phylogenetic tree of $60 \beta$-CA sequences was constructed (Fig. 5) which present the overall topology of identified clades, consistent with that found with other methods (maximum likelihood) and larger sets of $\beta$-CA sequences (data not shown). The analysis included sequences of the majority of previously described $\beta$-CAs as well as $\beta$-CAs
Table 3 Caut-bCAstrepC estimated molecular weights from $\mathrm{c}(\mathrm{s})$ and NIDS analysis by analytical ultracentrifugation

\begin{tabular}{|c|c|c|c|c|c|c|c|}
\hline \multirow{3}{*}{$\begin{array}{l}\text { Monomer MW } \\
(\mathrm{kDa})\end{array}$} & \multirow{3}{*}{$\begin{array}{l}\text { Detection } \\
\text { method }\end{array}$} & \multirow{3}{*}{$\begin{array}{l}\text { Concentration } \\
(\mathrm{mg} / \mathrm{mL})\end{array}$} & \multicolumn{5}{|c|}{ Major species } \\
\hline & & & \multicolumn{2}{|l|}{ Peak 1} & \multicolumn{2}{|c|}{ Peak 2} & \multirow[b]{2}{*}{$f f f_{0}^{\mathrm{a}}$} \\
\hline & & & $\begin{array}{l}\text { MW } \\
(\mathrm{kDa})\end{array}$ & $\begin{array}{l}\text { Sed. co } \\
\text { (S) }\end{array}$ & $\begin{array}{l}\text { MW } \\
(\mathrm{kDa})\end{array}$ & $\begin{array}{l}\text { Sed. Co } \\
\text { (S) }\end{array}$ & \\
\hline \multicolumn{8}{|l|}{$\mathrm{C}(\mathrm{s})$} \\
\hline & & 0.70 & 9.3 & 1.03 & 34.6 & 2.48 & 1.44 \\
\hline & Absorbance & 0.35 & 8.4 & 1.01 & 32.8 & 2.49 & 1.37 \\
\hline & & 0.18 & 9.3 & 1.02 & 35.1 & 2.48 & 1.45 \\
\hline \multirow[t]{3}{*}{15.2} & & 0.70 & - & - & 31.3 & 2.48 & 1.29 \\
\hline & Interference & 0.35 & 13.0 & 1.45 & 29.3 & 2.49 & 1.23 \\
\hline & & 0.18 & 11.9 & 1.32 & 30.6 & 2.48 & 1.27 \\
\hline \multicolumn{8}{|l|}{ NIDS } \\
\hline & & 0.70 & 10.1 & 1.04 & 29.3 & 2.49 & N/A \\
\hline \multirow[t]{2}{*}{15.2} & Absorbance & 0.35 & 9.7 & 1.02 & 29.4 & 2.51 & N/A \\
\hline & & 0.18 & 3.6 & 0.94 & 29.8 & 2.49 & N/A \\
\hline
\end{tabular}

${ }^{\text {a }}$ Best-fit frictional ratio $f_{0}$ 
from the major taxonomic groups of life. We identified six major clades within the $\beta$-CAs (Fig. 5). The A, B, C and $D$ clades are as described previously (Smith and Ferry 2000), and the E clade was formed by the former $\varepsilon$ CAs. The Caut-bCA-like proteins formed a distinct $\mathrm{F}$ clade, of not previously studied $\beta$-CAs.

An alignment of $160 \beta$-CA protein sequences was summarised as consensus logos for all six identified subclades (Online Resource 1). Only two motifs interspaced by $48-77$ amino acids were fully conserved in all selected $\beta$-CAs. These were the HxxC motifs, which bind the active site metal ion and the CxDxR motif that completes the active site (Rowlett 2010). Additional motifs were identified for subgroups of the clades. Enzymes in the A, B and C clades all contained a QxP motif of six amino acids N-terminal of the CxDxR motif, while $\mathrm{D}$ and $\mathrm{E}$ clades lack this motif. In most of the novel F clade, the QxP motif was found on the C-terminal side of the CxDxR motif. The A, B and $\mathrm{C}$ clades further contained a conserved $\mathrm{G}[\mathrm{D} / \mathrm{E}] \mathrm{xFxR}$ motif in sequence that was flanked by the CxDxR and HxxC motifs. In the E clade, only GxxF was conserved, and in the D clade, G $[\mathrm{D} / \mathrm{E}]$ was conserved. The distance between $\mathrm{CxDxR}$ and HxxC was larger than average in the E clade with approximately $75 \mathrm{aa}$, and to a lesser extent in the F clade with average distance of 64 aa, where A, B, C and D clades had an average distance of 55 aa.

Both phylogenetic and alignment analysis showed that the F clade was further split in two sub-clades, one defined by the putative $\beta$-CA of $M$. thermoacetica (MthermbCA-like) and the other by Caut-bCA. F clade CAs were mostly of shorter sequence than the previously described CAs of the other clades. The Mtherm-bCA-like subclade harbours six proteins of considerable length (172-183 aa). The Caut-bCA-like clade consists solely of relatively short CAs with a length of between 124 and 142 residues.

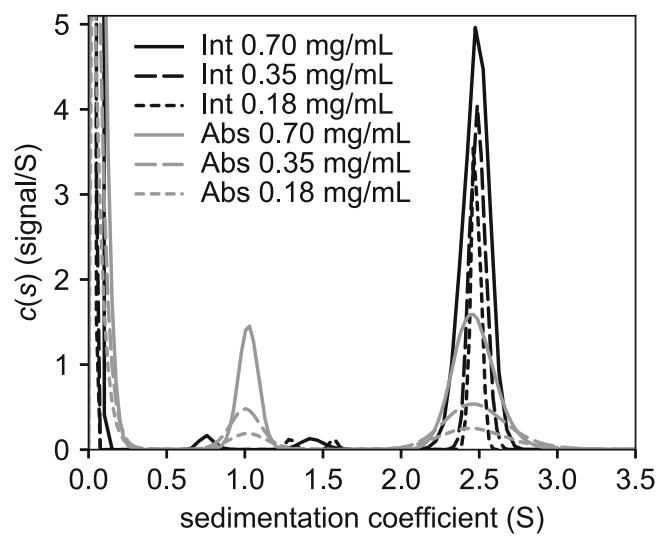

Fig. 4 Analytical ultracentrifuge analysis of Caut-bCAstrepC. c(s) distributions for Caut-bCAstrepC. Int, interference data; Abs, absorbance data. (The sharp peak at $\sim 0.1 \mathrm{~S}$ is buffer salt)

\section{Discussion}

Two putative CA genes, Caut-bCA and Caut-gCA, were identified in the genome of $C$. autoethanogenum as potential members of the $\beta$ - and $\gamma$-classes of CA. However, a low sequence similarity of Caut-bCA with other members of the $\beta-\mathrm{CA}$ and a reported lack of CA activity for several $\gamma$-CA homologs (Martin et al. 2009; Al-Haideri et al. 2016; Kaur et al. 2010; Ferry 2010), did not allow to ascribe CA function to either of these genes based on gene sequence alone. Neither transcription profile nor genomic contexts of the identified genes revealed a specific function for these genes. To assess CA activity for the proteins encoded by these genes, these were heterologously expressed in a Can disruption mutant of E. coli (strain EDCM636). This showed that Caut-bCA could complement the lack of CA activity in this strain while CautgCA did not. This confirmed that Caut-bCA is a carbonic anhydrase while Caut-gCA is not a functional CA in this context. The results of activity assays on purified Caut-gCA and Caut-bCA proteins were consistent with this complementation study as no tested gCA construct yielded any activity while the pMTLCaut-bCAstrepC constructs yielded active purified enzymes. We suspect that the bulky metal binding $10 \times$ His residue close to the metal ion-binding active site interfered with the activity of Caut-bCA N-terminal His-tag (Hochuli et al. 1988) on a pET16b plasmid expressed in BL21(DE3) pLysS cells and therefor did not reliably yield active enzyme. Since E. coli EDCM636 does not grow without Caut-bCA complementation, Caut-bCA must be produced as an active enzyme. We suspect that this further enhanced the reproducibility of this system.

The measured kinetic parameters were similar to other reported $\beta$-CAs. The $K_{\mathrm{M}}$ of $6.8 \mathrm{mM}$ was slightly higher than that for the $\beta$-CAs of Clostridium perfringens and Methanothermobacter thermautotrophicus but lower than those of Salmonella enterica or Helicobacter pylori. The particular low $K_{\mathrm{M}}$ of the $C$. perfringens $\mathrm{CA}$ is interpreted as an indication for a function in retaining intracellular levels for anaplerotic $\mathrm{CO}_{2}$ fixation reactions (Kumar et al. 2013).

The molecular weight of $\sim 30 \mathrm{kDa}$ determined by analytical ultra-centrifuge shows that Caut-bCA is a small dimeric protein. A Rhodospirilum rubrum CA was purified with a similar size $(28 \mathrm{kDa})$ and oligomeric state (dimer); however, no matching gene or protein sequence was identified, and later analysis of this species of $\beta$-CA showed larger sizes for its $\beta$ CA monomers (Gill et al. 1984; Smith et al. 1999). This makes Caut-bCA the smallest confirmed $\beta$-CA. The measured molecular weight of the dimer is close to some of the monomers of $\beta$-CAs of other species, illustrating the compact nature of Caut-bCA (Table 2).

Because of the low identity of the putative Caut-bCA with known $\beta$-CAs, further phylogenetic analysis was performed. We identified multiple orthologs of Caut-bCA in both bacteria 


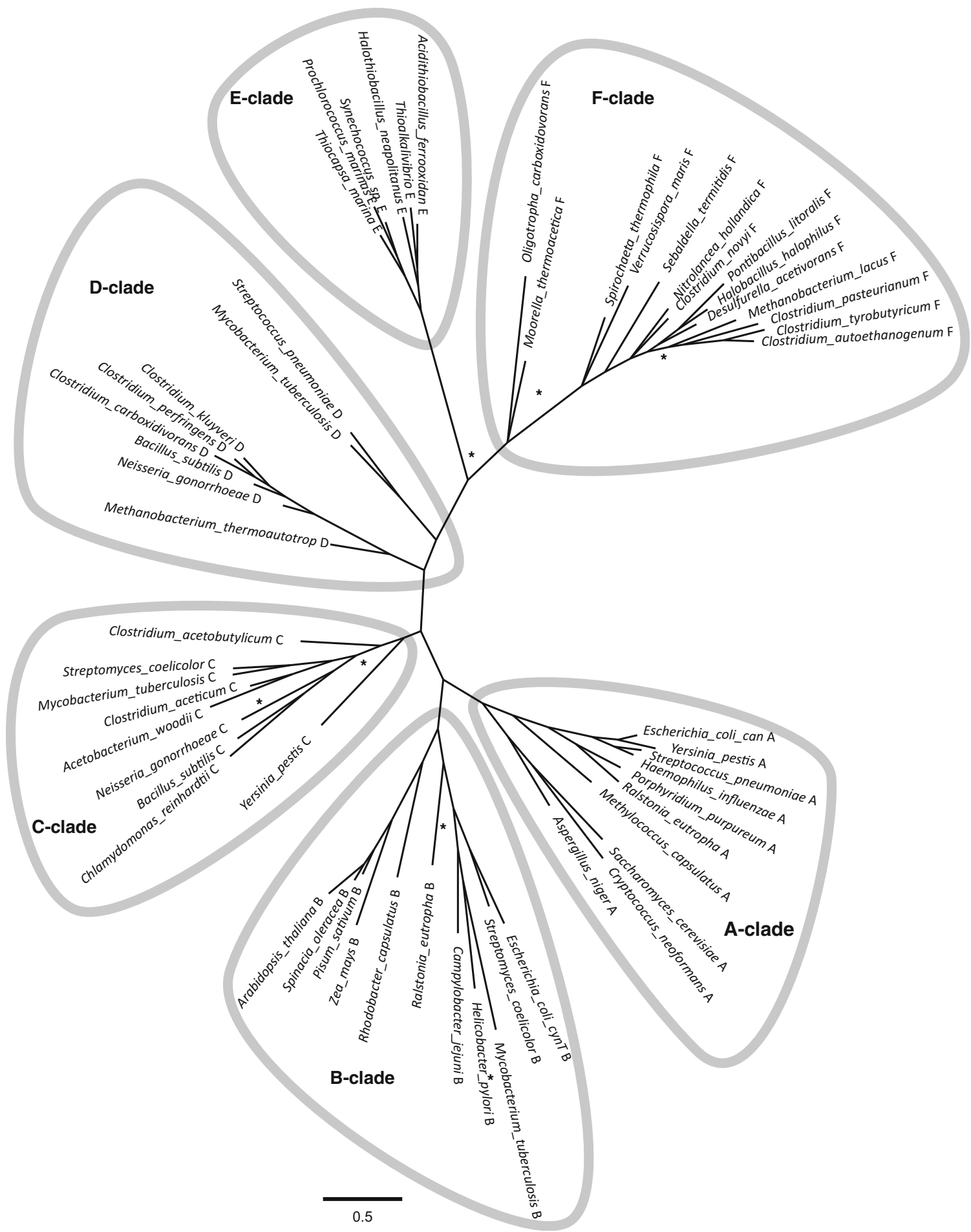

Fig. $5 \beta$-CA phylogeny. The phylogeny of $\beta$-CAs was reconstructed using MrBayes. All posterior probabilities are above 0.85 except for branches labelled with $*$ which have a probability between 0.55 and 0.7. A similar topology was obtained with more extended sets of

and archaea annotated as hypothetical genes. It was striking to find these specific Caut-bCA-like CA sequences relatively often in the deposited genomes of uncultivated bacteria and archaea or recent isolates of candidate species. However, we sequences, both with maximum Likelihood method and Bayesian analysis (data not shown). The tree was edited for clarity using Figtree and Inkscape

limited our further phylogenetic analysis to previously cultured species. The phylogenetic analysis revealed that the group of Caut-bCA-like CAs forms a distinct $\mathrm{F}$ clade of not previously studied $\beta$-CAs that are somewhat distantly related 
to the other $\beta$-CAs of the A, B, C and D subclasses. The further split of the F clade in two subclades (Mtherm-bCAlike and Caut-bCA-like) might be of consequence since M. thermoacetica showed little CA activity in previous studies (Braus-Stromeyer et al. 1997). Therefore, some caution is in place to assume functionality on the Mtherm-bCA-like proteins without further study. Based on the similarity of the Caut-bCA-like CAs to Caut-bCA, we assume that these are active CAs. Knowledge on CA in C. autoethanogenum could be used to improve $\mathrm{CO}_{2}$ utilization or to modulate product spectrum in vivo and for $\mathrm{CO}_{2}$ capture and storage in vitro (Alvizo et al. 2014; Warden et al. 2015; Lian et al. 2016).

Acknowledgments We would like to thank D.J. Kelly from the University of Sheffield for supplying $C$. jejuni $\beta$-CA Can used for assay validation.

Funding This work was supported by the Biotechnology and Biological Sciences Research Council (grant numbers BB/L502030/1, BB/ $\mathrm{K} 00283 \mathrm{X} / 1$ ) as part of the BBSRC Longer and Larger Grant GASCHEM and the industrial partner LanzaTech Inc. GH is supported by the Medical Research Council (UK) grant to the RCaH, and DJS is partially supported by the Science and Technology Facilities Council (UK).

\section{Compliance with ethical standards}

Conflict of interest BP declares that she has no conflict of interest.

GH declares that he has no conflict of interest.

DJS declares that he has no conflict of interest.

$\mathrm{KW}$ declares that he has no conflict of interest.

MK is employed by LanzaTech. LanzaTech has commercial interest in gas fermentation.

SDS is employed by LanzaTech. LanzaTech has commercial interest in gas fermentation.

NPM declares that he has no conflict of interest.

AMH declares that he has no conflict of interest.

Ethical approval This article does not contain any studies with human participants or animals performed by any of the authors.

Open Access This article is distributed under the terms of the Creative Commons Attribution 4.0 International License (http:// creativecommons.org/licenses/by/4.0/), which permits unrestricted use, distribution, and reproduction in any medium, provided you give appropriate credit to the original author(s) and the source, provide a link to the Creative Commons license, and indicate if changes were made.

\section{References}

Abrini J, Naveau H, Nyns E-J (1994) Clostridium autoethanogenum, sp. nov., an anaerobic bacterium that produces ethanol from carbon monoxide. Arch Microbiol 161:345-351. https://doi.org/10.1007/ BF00303591

Al-Haideri H, White M, Kelly DJ (2016) Major contribution of the type II beta carbonic anhydrase CanB (Cj0237) to the capnophilic growth phenotype of Campylobacter jejuni. Environ Microbiol 18:721735. https://doi.org/10.1111/1462-2920.13092
Alvizo O, Nguyen LJ, Savile CK, Bresson JA, Lakhapatri SL, Solis EOP, Fox RJ, Broering JM, Benoit MR, Zimmerman SA, Novick SJ, Liang J, Lalonde JJ (2014) Directed evolution of an ultrastable carbonic anhydrase for highly efficient carbon capture from flue gas. Proc Natl Acad Sci U S A 111:16436-16441. https://doi.org/10. 1073/pnas.1411461111

Braus-Stromeyer S, Schnappauf G, Braus G, Gossner A, Drake H (1997) Carbonic anhydrase in Acetobacterium woodii and other acetogenic bacteria. J Bacteriol 179:7197-7200

Cannon GC, Heinhorst S, Kerfeld CA (2010) Carboxysomal carbonic anhydrases: structure and role in microbial $\mathrm{CO}_{2}$ fixation. Biochim Biophys Acta 1804:382-392. https://doi.org/10.1016/j.bbapap. 2009.09.026

Capasso C, Supuran CT (2015) An overview of the alpha-, beta- and gamma-carbonic anhydrases from bacteria: can bacterial carbonic anhydrases shed new light on evolution of bacteria? J Enzyme Inhib Med Chem 30:325-332. https://doi.org/10.3109/14756366. 2014.910202

Darriba D, Taboada GL, Doallo R, Posada D (2011) ProtTest 3: fast selection of best-fit models of protein evolution. Bioinformatics 27:1164-1165. https://doi.org/10.1093/bioinformatics/btr088

Del Prete S, Vullo D, Fisher GM, Andrews KT, Poulsen S-A, Capasso C, Supuran CT (2014) Discovery of a new family of carbonic anhydrases in the malaria pathogen Plasmodium falciparum - the $\eta$-carbonic anhydrases. Bioorg Med Chem Lett 24:4389-4396. https://doi.org/10.1016/j.bmcl.2014.08.015

Diamond LW, Akinfiev NN (2003) Solubility of $\mathrm{CO}_{2}$ in water from - 1.5 to $100{ }^{\circ} \mathrm{C}$ and from 0.1 to $100 \mathrm{MPa}$ : evaluation of literature data and thermodynamic modelling. Fluid Phase Equilib 208:265-290. https://doi.org/10.1016/S0378-3812(03)00041-4

Edgar RC (2004) MUSCLE: multiple sequence alignment with high accuracy and high throughput. Nucleic Acids Res 32:1792-1797. https://doi.org/10.1093/nar/gkh340

Fasseas MK, Tsikou D, Flemetakis E, Katinakis P (2011) Molecular and biochemical analysis of the $\alpha$ class carbonic anhydrases in Caenorhabditis elegans. Mol Biol Rep 38:1777-1785. https://doi. org/10.1007/s11033-010-0292-y

Ferry JG (2010) The gamma class of carbonic anhydrases. Biochim Biophys Acta 1804:374-381. https://doi.org/10.1016/j.bbapap. 2009.08.026

Gai CS, Lu J, Brigham CJ, Bernardi AC, Sinskey AJ (2014) Insights into bacterial $\mathrm{CO}_{2}$ metabolism revealed by the characterization of four carbonic anhydrases in Ralstonia eutropha H16. AMB Express 4:2. https://doi.org/10.1186/2191-0855-4-2

Gasteiger E, Hoogland C, Gattiker A, Duvaud S, Wilkins MR, Appel RD, Bairoch A (2005) Protein identification and analysis tools in the ExPASy server. In: Walk JM (ed) Proteomics protoc. handbook. Humana Press, New York 2005

Gill SR, Fedorka-Cray PJ, Tweten RK, Sleeper BP (1984) Purification and properties of the carbonic anhydrase of Rhodospirillum rubrum. Arch Microbiol 138:113-118. https://doi.org/10.1007/BF00413010

Guilloton MB, Lamblin AF, Kozliak EI, Gerami-Nejad M, Tu C, Silverman D, Anderson PM, Fuchs JA (1993) A physiological role for cyanate-induced carbonic anhydrase in Escherichia coli. J Bacteriol 175:1443-1451

Hawkins AS, McTernan PM, Lian H, Kelly RM, Adams MW (2013) Biological conversion of carbon dioxide and hydrogen into liquid fuels and industrial chemicals. Curr Opin Biotechnol 24:376-384. https://doi.org/10.1016/j.copbio.2013.02.017

Heap JT, Pennington OJ, Cartman ST, Minton NP (2009) A modular system for Clostridium shuttle plasmids. J Microbiol Methods 78: 79-85. https://doi.org/10.1016/J.MIMET.2009.05.004

Heinhorst S, Williams EB, Cai F, Murin CD, Shively JM, Cannon GC (2006) Characterization of the carboxysomal carbonic anhydrase CsoSCA from Halothiobacillus neapolitanus. J Bacteriol 188: 8087-8094. https://doi.org/10.1128/JB.00990-06 
Hewett-Emmett D, Tashian RE (1996) Functional diversity, conservation, and convergence in the evolution of the alpha-, beta-, and gammacarbonic anhydrase gene families. Mol Phylogenet Evol 5:50-77. https://doi.org/10.1006/mpev.1996.0006

Hochuli E, Bannwarth W, Döbeli H, Gentz R, Stüber D (1988) Genetic approach to facilitate purification of recombinant proteins with a novel metal chelate adsorbent. Nat Biotechnol 6:1321-1325. https://doi.org/10.1038/nbt1188-1321

Innocenti A, Mühlschlegel FA, Hall RA, Steegborn C, Scozzafava A, Supuran CT (2008) Carbonic anhydrase inhibitors: inhibition of the $\beta$-class enzymes from the fungal pathogens Candida albicans and Cryptococcus neoformans with simple anions. Bioorg Med Chem Lett 18:5066-5070. https://doi.org/10.1016/j.bmcl.2008.07.122

Iqbal S, Nisar-ur-Rahman, Iqbal J (2014) A capillary electrophoresisbased enzyme assay for kinetics and inhibition studies of carbonic anhydrase. Anal Biochem 444:16-21. https://doi.org/10.1016/j.ab. 2013.09.018

Iverson TM, Alber BE, Kisker C, Ferry JG, Rees DC (2000) A closer look at the active site of $\gamma$-class carbonic anhydrases: highresolution crystallographic studies of the carbonic anhydrase from Methanosarcina thermophila. Biochemistry 39:9222-9231. https:// doi.org/10.1021/bi000204s

Johanson IM, Forsman C (1993) Kinetic studies of pea carbonic anhydrase. Eur J Biochem 218:439-446. https://doi.org/10.1111/j. 1432-1033.1993.tb18394.x

Kaur S, Mishra MN, Tripathi AK (2010) Gene encoding gamma-carbonic anhydrase is cotranscribed with $\operatorname{argC}$ and induced in response to stationary phase and high $\mathrm{CO}_{2}$ in Azospirillum brasilense Sp7. BMC Microbiol 10:184. https://doi.org/10.1186/1471-2180-10-184

Kelley LA, Mezulis S, Yates CM, Wass MN, Sternberg MJE (2015) The Phyre2 web portal for protein modeling, prediction and analysis. Nat Protoc 10:845-858. https://doi.org/10.1038/nprot.2015.053

Kernohan JC (1964) The activity of bovine carbonic anhydrase in imidazole buffers. Biochim Biophys Acta - Spec Sect Enzymol Subj 81: 346-356. https://doi.org/10.1016/0926-6569(64)90050-1

Kisiel W, Graf G (1972) Purification and characterization of carbonic anhydrase from Pisum sativum. Phytochemistry 11:113-117. https://doi.org/10.1016/S0031-9422(00)89975-6

Köpke M, Mihalcea C, Liew F, Tizard JH, Ali MS, Conolly JJ, Al-Sinawi B, Simpson SD (2011) 2,3-Butanediol production by acetogenic bacteria, an alternative route to chemical synthesis, using industrial waste gas. Appl Environ Microbiol 77:5467-5475. https://doi.org/ 10.1128/AEM.00355-11

Kumar RSS, Ferry JG (2014) Prokaryotic carbonic anhydrases of Earth's environment. Subcell Biochem 75:77-87. https://doi.org/10.1007/ 978-94-007-7359-2 5

Kumar RSS, Hendrick W, Correll JB, Patterson AD, Melville SB, Ferry JG (2013) Biochemistry and physiology of the $\beta$ class carbonic anhydrase $(\mathrm{Cpb})$ from Clostridium perfringens strain 13. J Bacteriol 195:2262-2269. https://doi.org/10.1128/JB.02288-12

Kumar S, Stecher G, Tamura K (2016) MEGA7: molecular evolutionary genetics analysis version 7.0 for bigger datasets. Mol Biol Evol 33: 1870-1874. https://doi.org/10.1093/molbev/msw054

Kusian B, Sültemeyer D, Bowien B (2002) Carbonic anhydrase is essential for growth of Ralstonia eutropha at ambient $\mathrm{CO}(2)$ concentrations. J Bacteriol 184:5018-5026. https://doi.org/10.1128/JB.184. $18.5018-5026.2002$

Lian H, Zeldes BM, Lipscomb GL, Hawkins AB, Han Y, Loder AJ, Nishiyama D, Adams MWW, Kelly RM (2016) Ancillary contributions of heterologous biotin protein ligase and carbonic anhydrase for $\mathrm{CO}_{2}$ incorporation into 3-hydroxypropionate by metabolically engineered Pyrococcus furiosus. Biotechnol Bioeng 113:26522660. https://doi.org/10.1002/bit.26033

Lindskog S (1997) Structure and mechanism of carbonic anhydrase. Pharmacol Ther 74:1-20. https://doi.org/10.1016/S0163-7258(96) 00198-2
Marcellin E, Behrendorff JB, Nagaraju S, DeTissera S, Segovia S, Palfreyman R, Daniell J, Licona-Cassani C, Quek L, Speight R, Hodson MP, Simpson SD, Mitchell WP, Köpke M, Nielsen LK (2016) Low carbon fuels and commodity chemicals from waste gases - systematic approach to understand energy metabolism in a model acetogen. Green Chem 1:3020-3028. https://doi.org/10. 1039/C5GC02708J

Martin V, Villarreal F, Miras I, Navaza A, Haouz A, González-Lebrero RM, Kaufman SB, Zabaleta E (2009) Recombinant plant gamma carbonic anhydrase homotrimers bind inorganic carbon. FEBS Lett 583:3425-3430. https://doi.org/10.1016/j.febslet.2009.09.055

Merlin C, Masters M, McAteer S, Coulson A (2003) Why is carbonic anhydrase essential to Escherichia coli? J Bacteriol 185:6415-6424. https://doi.org/10.1128/JB.185.21.6415-6424.2003

Michaelis L, Menten ML (1913) Die kinetik der invertinwirkung. Biochem Z 49:333-369

Moroney JV, Bartlett SG, Samuelsson G (2001) Carbonic anhydrases in plants and algae. Plant Cell Environ 24:141-153. https://doi.org/10. 1111/j.1365-3040.2001.00669.x

Moroney JV, Ma Y, Frey WD, Fusilier KA, Pham TT, Simms TA, DiMario RJ, Yang J, Mukherjee B (2011) The carbonic anhydrase isoforms of Chlamydomonas reinhardtii: intracellular location, expression, and physiological roles. Photosynth Res 109:133-149. https://doi.org/10.1007/s11120-011-9635-3

Nishimori I, Minakuchi T, Vullo D, Scozzafava A, Supuran CT (2011) Inhibition studies of the $\beta$-carbonic anhydrases from the bacterial pathogen Salmonella enterica serovar Typhimurium with sulfonamides and sulfamates. Bioorg Med Chem 19:5023-5030. https:// doi.org/10.1016/j.bmc.2011.06.038

Okonechnikov K, Golosova O, Fursov M, UGENE Team (2012) Unipro UGENE: a unified bioinformatics toolkit. Bioinformatics 28:11661167. https://doi.org/10.1093/bioinformatics/bts091

Rambaut A (2014) Figtree v1.4.2. http://tree.bio.ed.ac.uk/software/ figtree/. Accessed 19 June 2019

Ronquist F, Teslenko M, van der Mark P, Ayres DL, Darling A, Höhna S, Larget B, Liu L, Suchard MA, Huelsenbeck JP (2012) MrBayes 3.2: efficient Bayesian phylogenetic inference and model choice across a large model space. Syst Biol 61:539-542. https:/doi.org/10.1093/ sysbio/sys029

Rowlett RS (2010) Structure and catalytic mechanism of the betacarbonic anhydrases. Biochim Biophys Acta 1804:362-373. https://doi.org/10.1016/j.bbapap.2009.08.002

Sachs G, Weeks DL, Wen Y, Marcus EA, Scott DR, Melchers K (2005) Acid acclimation by Helicobacter pylori. Physiology 20:429-438. https://doi.org/10.1152/physiol.00032.2005

Sawaya MR, Cannon GC, Heinhorst S, Tanaka S, Williams EB, Yeates TO, Kerfeld CA (2006) The structure of beta-carbonic anhydrase from the carboxysomal shell reveals a distinct subclass with one active site for the price of two. J Biol Chem 281:7546-7555. https://doi.org/10.1074/jbc.M510464200

Sayers EW, Barrett T, Benson DA, Bolton E, Bryant SH, Canese K, Chetvernin V, Church DM, Dicuccio M, Federhen S, Feolo M, Fingerman IM, Geer LY, Helmberg W, Kapustin Y, Krasnov S, Landsman D, Lipman DJ, Lu Z, Madden TL, Madej T, Maglott DR, Marchler-Bauer A, Miller V, Karsch-Mizrachi I, Ostell J, Panchenko A, Phan L, Pruitt KD, Schuler GD, Sequeira E, Sherry ST, Shumway M, Sirotkin K, Slotta D, Souvorov A, Starchenko G, Tatusova TA, Wagner L, Wang Y, Wilbur WJ, Yaschenko E, Ye J (2012) Database resources of the National Center for Biotechnology Information. Nucleic Acids Res 40:D13-D25. https://doi.org/10. 1093/nar/gkr1184

Schmidt TG, Skerra A (2007) The Strep-tag system for one-step purification and high-affinity detection or capturing of proteins. Nat Protoc 2:1528-1535. https://doi.org/10.1038/nprot.2007.209

Schuck P (2000) Size-distribution analysis of macromolecules by sedimentation velocity ultracentrifugation and Lamm equation 
modeling. Biophys J 78:1606-1619. https://doi.org/10.1016/S00063495(00)76713-0

Simpson SD, Koepke M, Smart KF, Tran LP, Sechrist P (2014) System and method for controlling metabolite production in a microbial fermentation. https://patents.google.com/patent/WO2014151158A1. Accessed 19 June 2019

Smith KS, Ferry JG (1999) A plant-type (beta-class) carbonic anhydrase in the thermophilic methanoarchaeon Methanobacterium thermoautotrophicum. J Bacteriol 181:6247-6253

Smith KS, Ferry JG (2000) Prokaryotic carbonic anhydrases. FEMS Microbiol Rev 24:335-366. https://doi.org/10.1016/S01686445(00)00030-9

Smith KS, Jakubzick C, Whittam TS, Ferry JG (1999) Carbonic anhydrase is an ancient enzyme widespread in prokaryotes. Proc Natl Acad Sci 96:15184-15189. https://doi.org/10.1073/pnas.96. 26.15184

Smith KS, Ingram-Smith C, Ferry JG (2002) Roles of the conserved aspartate and arginine in the catalytic mechanism of an archaeal class carbonic anhydrase. J Bacteriol 184:4240-4245. https://doi. org/10.1128/JB.184.15.4240-4245.2002

Sundaram V, Rumbolo P, Grubb J, Strisciuglio P, Sly WS (1986) Carbonic anhydrase II deficiency: diagnosis and carrier detection using differential enzyme inhibition and inactivation. Am J Hum Genet 38:125-136

Supuran CT (2016) Structure and function of carbonic anhydrases. Biochem J 473:2023-2032. https://doi.org/10.1042/BCJ20160115

Supuran CT, Ferry JG (2013) Carbonic anhydrases of anaerobic microbes. Bioorg Med Chem 21:1392-1395

Supuran CT, Scozzafava A (2007) Carbonic anhydrases as targets for medicinal chemistry. Bioorg Med Chem 15:4336-4350. https:// doi.org/10.1016/j.bmc.2007.04.020
Syrjänen L, Tolvanen M, Hilvo M, Olatubosun A, Innocenti A, Scozzafava A, Leppiniemi J, Niederhauser B, Hytönen VP, Gorr TA, Parkkila S, Supuran CT (2010) Characterization of the first beta-class carbonic anhydrase from an arthropod (Drosophila melanogaster) and phylogenetic analysis of beta-class carbonic anhydrases in invertebrates. BMC Biochem 11:28. https://doi.org/ 10.1186/1471-2091-11-28

Ueda K, Tagami Y, Kamihara Y, Shiratori H, Takano H, Beppu T (2008) Isolation of bacteria whose growth is dependent on high levels of $\mathrm{CO}_{2}$ and implications of their potential diversity. Appl Environ Microbiol 74:4535-4538. https://doi.org/10.1128/AEM.00491-08

Ueda K, Nishida H, Beppu T (2012) Dispensabilities of carbonic anhydrase in proteobacteria. Int J Evol Biol 2012:324549. https:// doi.org/10.1155/2012/324549

Warden AC, Williams M, Peat TS, Seabrook SA, Newman J, Dojchinov G, Haritos VS (2015) Rational engineering of a mesohalophilic carbonic anhydrase to an extreme halotolerant biocatalyst. Nat Commun 6:10278. https://doi.org/10.1038/ncomms10278

Waterhouse AM, Procter JB, Martin DMA, Clamp M, Barton GJ (2009) Jalview version 2 -a multiple sequence alignment editor and analysis workbench. Bioinformatics 25:1189-1191. https://doi.org/10. 1093/bioinformatics/btp033

Wilbur KM, Anderson NG (1948) Electrometric and colorimetric determination of carbonic anhydrase. J Biol Chem 176:147-154

Publisher's note Springer Nature remains neutral with regard to jurisdictional claims in published maps and institutional affiliations. 